\title{
Improving the quality of foods available in a rural kibbutz cafeteria in Israel to align with a freshly prepared Mediterranean-style diet through a community culinary coaching programme
}

\author{
Rani Polak ${ }^{1,2,3, *}$, David Pober ${ }^{4}$, Elliot M Berry ${ }^{5}$, Tehila Mazal ${ }^{5}$, Rakefet Arieli 6 and \\ Mati Ziv ${ }^{7}$ \\ ${ }^{1}$ Institute of Lifestyle Medicine, Spaulding Rehabilitation Hospital, 3001 st Avenue, Boston, MA 02129, USA: \\ ${ }^{2}$ Department of Physical Medicine \& Rehabilitation, Harvard Medical School, Boston, MA, USA: ${ }^{3}$ Healthy Cooking \\ and Lifestyle Center, Department of Family Medicine, Hebrew University Hadassah Medical School, Jerusalem, Israel: \\ ${ }^{4}$ Joslin Diabetes Center, Harvard Medical School, Boston, MA, USA: ${ }^{5}$ Department of Human Nutrition \& Metabolism, \\ Braun School of Public Health, Hebrew University Hadassah Medical School, Jerusalem Israel: 'Sport Medicine Center, \\ Department of Orthopedic Surgery, The Hadassah-Hebrew University Medical Center, Jerusalem, Israel: ${ }^{7}$ Department \\ of Family Medicine, Sackler School of Medicine, Tel Aviv University, Tel Aviv, Israel
}

Submitted 15 May 2018: Final revision received 4 April 2019: Accepted 15 April 2019: First published online 22 July 2019

\begin{abstract}
Objective: To examine the impact of a community culinary coaching programme (CCCP) on cafeteria food alignment with a freshly prepared Mediterranean-style diet, and diners' consumption habits and satisfaction.

Design: A non-randomized, controlled, community-based participatory research programme. CCCP included eight 90 min coaching sessions with a community steering committee, $22 \mathrm{~h}$ of kitchen staff training, $12 \mathrm{~h}$ of pre-school staff training and $30 \mathrm{~h}$ of education for diners; control communities received no intervention. Outcomes, measured before and 12 months after programme initiation, included cafeteria food alignment with a freshly prepared Mediterranean-style diet through a food items list derived from the cafeteria food purchasing software, and adult diners' consumption habits and satisfaction through questionnaires.

Setting: Communal cafeterias of rural kibbutzim.

Participants: Intervention: kibbutz with 493 adults and 214 children. Control: Two kibbutzim with a total of 487 adults and 206 children.

Results: Intervention cafeteria food improved significantly in all Mediterranean index categories except nuts (legumes, wholegrain products, fish, MUFA/SFA $P<0.0001$; fruits, vegetables $P<0.001$; processed meats $P=0.004)$, and in the proportion of ultra-processed and unprocessed or minimally processed foods categories of the NOVA classification $(-22 \%, P<0.001$ and $+7 \%, P<0.001$, respectively), compared with the control community. The intervention group's satisfaction was significantly improved in twenty-five (83\%) out of the thirty satisfaction items, compared with twelve (40\%) in the control group. No changes were identified in diners' consumption habits in either intervention or control communities.

Conclusions: CCCP might be useful in improving alignment of cafeteria food with a freshly prepared Mediterranean-style diet.
\end{abstract}

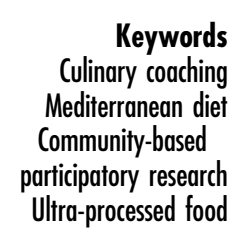

Keywords Culinary coaching Mediterranean diet Community-based Ultra-processed food
Unhealthy diet patterns, which consequently increase the risk for chronic diseases, have been identified as a public health concern in Israel $^{(1)}$. The Israeli diabetes prevalence is 105 th among 220 countries, with 416000 adults (8.2\%) who have diabetes, and this prevalence is projected to rise to 695000 by $2045^{(2)}$. In 2017 , the total Israeli health-care expenditure on diabetes reached $\$$ US 1.72 billion and is projected to reach $\$$ US 2.54 billion by $2045^{(2)}$. Despite these 
alarming projections, only $26 \%$ of the Israeli population reports maintaining a healthy $\operatorname{diet}^{(3)}$; thus, improving eating behaviour is a major Israeli public health priority ${ }^{(1)}$. While individual-level behavioural change efforts can be partly effective, healthy eating habits are more likely to occur in a supportive environment with accessible and affordable healthy food choices ${ }^{(4)}$. Therefore, effective and sustainable strategies are needed to improve the availability of healthy food choices in working places and schools.

Culinary education is an emerging strategy ${ }^{(5)}$ that has proved effective in improving patients' adherence to healthy diets ${ }^{(6,7)}$. However, the literature that describes professional kitchen staff's culinary education as a strategy to improve cafeteria food, and thus community nutrition, is limited. Indeed, most cafeteria interventions have included methods such as food labelling and food architecture ${ }^{(8-10)}$, and the kitchen staff were identified as a potential barrier for change ${ }^{(11)}$. Effective, long-term methods are needed that will enable researchers to collaborate with kitchen staff to empower them to improve the availability of healthy food options in cafeterias.

A kibbutz is a communal settlement based on socialist ideology ${ }^{(12)}$ and is among the most economically homogeneous societies in the Western world. Members live as a cooperative community, sharing income and expenses, working within a communal budget and eating food that is prepared in the community cafeteria. Several publications looked at various health aspects (e.g. disability in \left.${\text { older } \text { adults }^{(13)} \text {, health-care utilization }}^{(14)}\right)$ of this unique community, however the potential of leveraging this community structure to improve members' eating behaviour was never explored. Our goal was to implement an effective and sustainable nutritional change through collaborating with a kibbutz leadership including the cafeteria staff using community-based participatory research (CBPR) principles $^{(15,16)}$.

Culinary coaching is a behavioral intervention that aims to improve nutrition and overall health by facilitating home cooking through an active learning process for participants that combines culinary training with health and wellness coaching competencies'(17). Culinary coaching engages clients as an active and autonomous, self-motivated partner to facilitate culinary change through strategies such as client-directed goal-setting, guided self-discovery and client-directed culinary training ${ }^{(18-20)}$. Previous publications describe the use and potential impact of culinary coaching in patient programmes that aim to improve nutrition of individuals and families ${ }^{(17,21)}$. However, culinary coaching might also be the foundation of a CBPR programme that focuses on collaborating with community leadership and kitchen staff as equivalent partners to effectively improve community nutrition.

The community culinary coaching programme (CCCP) is an innovative $\mathrm{CBPR}$ programme aimed at improving community members' nutrition through the culinary coaching approach. The Mediterranean diet is rich in fresh fruits and vegetables, legumes, whole grains, fish and low-fat dairy products ${ }^{(22)}$. This diet has been proved effective in reducing ${ }^{(23,24)}$ and maintaining weight ${ }^{(25)}$, in preventing $\mathrm{CVD}^{(26)}$ and in reducing the incidence of cancer ${ }^{(27)}$. In addition, there is growing evidence that supports the importance of food quality, including decreasing ultra-processed food items ${ }^{(28)}$ that were found to contribute to cardiometabolic disorders (e.g. obesity ${ }^{(29)}$, hypertension ${ }^{(30)}$, dyslipidaemia $\left.{ }^{(31)}\right)$ and cancer $^{(32)}$. Therefore, the nutritional foundation of the CCCP was chosen to be a freshly prepared Mediterranean-style diet.

A previous publication has described the programme development and process evaluation ${ }^{(20)}$. The aim of the present paper is to describe the programme's impact on the alignment of the cafeteria food with a freshly prepared Mediterranean-style diet, and community members' consumption habits and satisfaction; and to collect data on the change in food costs. We hypothesized that the cafeteria's food alignment with a freshly prepared Mediterraneanstyle diet would be significantly improved, without change in diners' consumption habits (e.g. frequency of dining, frequency of family meals) and satisfaction, in comparison to control kibbutzim and their diners.

\section{Methods}

The CCCP was a 12-month CBPR founded by the intervention community administration, who partnered with our research team to improve the food served by the community cafeteria. The community administration identified priorities and key principles for the intervention. Priorities included providing healthier options in the communal cafeteria, which also serves food to the pre-school, and delivering educational programmes for the members and the professional staff of both the pre-school and the cafeteria. Key programme principles included focusing on a freshly prepared Mediterranean-style diet (rich in fresh fruits and vegetables, legumes, whole grains, olive oil, fish and low-fat dairy products ${ }^{(22)}$ and low in ultraprocessed food items ${ }^{(28)}$ ), and participation of the community in the process by employing the culinary coaching approach $^{(17)}$. This allowed the community representatives both to be an equal partner in determining the desired process and outcomes, and to be trained by the programme faculty in the Mediterranean cooking principles. Detailed description about the intervention development and components is presented elsewhere ${ }^{(20)}$, and is described briefly below. Control communities were followed-up without having nutritional instruction nor coaching sessions.

\section{Community culinary coaching programme}

A community steering committee was assembled by the kibbutz's administration aimed at representing the 
community in leading the intervention development and implementation. It included the community's secretary, health coordinator, food administrator, cafeteria manager, family physician, nurse practitioner and workplace humanresource manager who was appointed the community's project manager. The CCCP included both a coaching and a training component.

\section{The bealth coaching component}

The steering committee participated in eight $90 \mathrm{~min}$ inperson group culinary coaching sessions (one every 6 weeks) with one of the programme coaches (i.e. a family physician who is also a credentialled chef (R.P.) and a registered dietitian (R.A.), both of whom were formally trained in coaching techniques). During each culinary coaching session, the steering committee reviewed the implementation of the intervention goals and community feedback and identified goals for the next 6-week period. Culinary coaching sessions included group and individual coaching strategies designed to build a strong alliance and activate engagement in the process of change, including brainstorming, goal-setting, motivational interviewing and a self-discovery process ${ }^{(21)}$.

\section{The training component}

The training component included training programmes for both the professional staff and interested community members, whereas each programme's scope and content areas were identified during the culinary coaching meetings. The final training included a $22 \mathrm{~h}$ training programme for the kitchen staff; a $12 \mathrm{~h}$ training programme for pre-school staff; and three $4 \mathrm{~h}$ cooking modules and nine $2 \mathrm{~h}$ nutritional modules for community members. Content areas were focused on a freshly prepared Mediterranean-style diet including cooking plant-based protein items (e.g. lentils, beans) and how to impact nutritional change among children.

\section{Setting and participants}

The intervention setting was a rural kibbutz with 493 adults and 241 children. Two kibbutzim in the same district with a total of 487 adults and 206 children, with similar sociodemographic and health parameters ${ }^{(33)}$, were chosen as a control group. Three buffet-style meals per day are served (lunch is the main meal) in these three kibbutzim, and are freely available to members, most of whom work within the kibbutzim (an additional 160 employees work at the intervention kibbutz and have lunch in the cafeteria). Food can also be taken away by members to eat at home, and separate menus are delivered to the community preschool. Inclusion criteria for participating in the diners' consumption habits and satisfaction evaluation were: over 18 years of age, not pregnant or less than 3 months after giving birth and eating at least one meal in the communal cafeteria per day. This project was approved by the Clalit Health Service Institutional Review Board on Human
Subjects Research (committee's reference number 0030$12-\mathrm{COM}$ ) and the need for participant consent was waived.

\section{Outcome measures}

The impact of the CCCP was measured through three outcomes before and 12 months after programme initiation: (i) alignment of the cafeteria food with a freshly prepared Mediterranean-style diet using the Mediterranean index ${ }^{(24,34)}$ and the NOVA classification for processed foods ${ }^{(28)}$; (ii) community members' satisfaction and consumption habits; and (iii) food costs.

Changes in the alignment of the cafeteria food with a freshly prepared Mediterranean-style diet were measured by comparing the total food purchases pre-intervention with those 12 months after initiation, using a 3-month sample taken from the kitchen food purchasing software. The months June through August were taken as a representative of typical purchasing; purchase lists 12 months from initiation were corrected to the overall change in the food purchased by each community throughout the year. Changes in the food costs were measured by comparing the total food costs of the two 3-month samples. Costs were corrected to the differences in the Israeli food cost indices between 2012 and 2013 ${ }^{(35)}$ (Israeli fruits and vegetables price index, Israeli food price index without fruits and vegetables).

A questionnaire, based on previous validated questionnaires ${ }^{(36,37)}$, was developed in partnership with the community administration and was administered to community members both in the community clinic and in the communal cafeteria. It included the following domains. (i) Diners' consumption habits through three questions that evaluated how often members ate or took away food from the cafeteria at breakfast, lunch and dinner ( $1=$ once per week to $7=$ seven times per week $)$ and the number of family meals per week ( $1=$ once per week to $7=$ seven times per week); and Likert-scale questions evaluating how often responders refilled their plate during an average meal $(1=$ no refills to $4=$ three times or more). (ii) Diners' satisfaction with the food service, assessed through sixteen Likert-scale questions evaluating the satisfaction from breakfasts, lunches, dinners and Friday night dinners with regard to taste, variety, health and overall ( $1=$ not satisfied at all to $4=$ very satisfied); and fourteen Likert-scale questions evaluating satisfaction from specific food items served in the cafeteria $(1=$ not satisfied at all to $4=$ very satisfied). Five demographic items including age, sex, marital status, having children (under the age of 18 years) and country of origin were added to the questionnaire.

\section{Statistical analysis}

Demographic variables were assessed using Student's $t$ test or the $\chi^{2}$ test as appropriate to the distribution of each variable. Mediterranean index and NOVA classification 
Table 1 Demographic characteristics of the intervention (rural kibbutz with 493 adults and 214 children) and control groups (two rural kibbutzim with a total of 487 adults and 206 children), Israel, November 2012-October 2013

\begin{tabular}{lccc}
\hline & Intervention & Control & $P$ \\
\hline Sex (female; \%) & 57 & 53 & 0.46 \\
Age (years) & 55.3 & 52.7 & 0.04 \\
Location of birth (\%) & & & $<0.0001$ \\
$\quad$ Israel & 81 & 46 & \\
$\quad$ Europe & 3 & 13 & \\
$\quad$ North America & 7 & 33 & \\
Marital status (\%) & & & 0.15 \\
$\quad$ Married & 81 & 82 & \\
$\quad$ Single & 6 & 3 & \\
$\quad$ Divorced & 9 & 11 & \\
Have children under the age of & 53 & 67 & 0.03 \\
$\quad$ 18 years (\%) & 11 & 13 & 0.45 \\
$\quad$ Vegetarian (\%) & 26 & 29 & 0.51 \\
$\quad$ Health-related nutritional specific & 26 & & \\
$\quad$ requirements (e.g. disease, & & & \\
$\quad$ allergy, food intolerance; \%) & & & \\
\hline
\end{tabular}

categories were assessed by generalized linear mixedeffects models (PROC GLIMMIX) using the statistical software package SAS version 9.4. Questionnaire measures were assessed using linear mixed-effects models (PROC MIXED) and $P$ values were adjusted (increased) for the multiplicity of questionnaire items to control the false discovery rate at 0.05 using the method of Benjamini and Hochberg ${ }^{(38)}$. Questionnaire and food category outcome analyses were adjusted for differences in age, location of birth (as a categorical variable) and presence of children in the household, as these demographic factors differed significantly between intervention and control communities. These adjustments did not affect the direction or significance of any conclusions.

\section{Results}

The CCCP was delivered from November 2012 through October 2013. Two hundred and ten adults from the intervention group completed the questionnaire before the intervention and 232 at 12 months from initiation; 185 adults from the control group completed the questionnaire before the intervention and 193 at 12 months from initiation. Table 1 presents demographic characteristics. The respondents in the control group were somewhat younger $(P=0.04)$, more had children under the age of 18 years $(P=0.03)$ and were composed of more immigrants $(P<0.0001)$ than the intervention group.

Table 2 presents the changes in the Mediterranean index food categories. The food purchased by the intervention kibbutz cafeteria improved its alignment with the Mediterranean index in most categories (legumes, $+15 \%$, $P<0.001$; wholegrain products $+127 \%, P<0.0001$; nuts $+15 \%, P<0.001$; vegetables $+9 \%, P<0.001$; MUFA $/$ SFA $+31 \%, P<0.0001$; processed meats $-17 \%, P<0.0001$; fish
$+116 \%, P<0.0001)$. The only category that was not improved was fruits, which was also the only category that was not included in the community goals during the programme (alcoholic beverages are not served in this setting) ${ }^{(20)}$. Over the same period, the food purchased by the control kibbutzim cafeterias decreased its alignment with the Mediterranean index in all categories except nuts and processed meats (all $P<0.001$ ). This resulted in significantly greater improvement in all categories except nuts in the intervention community as compared with the control (legumes, wholegrain products, fish, MUFA/SFA $P<0.0001$; fruits, vegetables $P<0.001$; processed meats $P=0.004)$.

Table 3 presents the changes in the NOVA food classification of both the intervention and the control groups. The proportion of ultra-processed food items that was purchased by the intervention group cafeteria decreased by $22 \%(P<0.001)$ with a reciprocal increase in the unprocessed or minimally processed foods category $(+7 \%$, $P=0.01$ ), compared with a non-significant decrease of the unprocessed or minimally processed foods and nonsignificant increase in the ultra-processed food categories served by control cafeterias. This resulted in a significantly greater improvement in both categories in the intervention community compared with control (both $P<0 \cdot 001$ ).

The total food costs of the intervention cafeteria 12 months from the beginning of the intervention increased by $10 \%$, while the total purchased food (kilograms) increased by $6 \%$. In comparison, during the same time, the food costs of the control group increased by $1 \%$ while the total food purchased (kilograms) decreased by $3 \%$. No change was reported in workforce costs consequent to the intervention.

Table 4 presents the changes in community members' satisfaction with the cafeteria food. In twenty-five (83\%) out of the thirty satisfaction items, intervention community members' satisfaction was significantly improved 12 months from intervention initiation, in comparison to twelve ( $40 \%)$ in the control group. However, changes in only nine out of these twenty-five satisfaction items improved selectively between groups. These included mostly changes around lunch (e.g. health, overall), which was the main target of the community goals; and in specific food items (e.g. salad, starch dishes, vegetable side dishes). Table 5 presents the changes that were reported in the diners' consumption habits. Neither the intervention nor the control community diners reported changing their consumption habits significantly.

\section{Discussion}

The current paper presents the positive impact of a CCCP on the alignment of a rural kibbutz cafeteria food with a freshly prepared Mediterranean-style diet. While these outcomes are consistent with other CBPR programmes for 
Table 2 Mediterranean index of food purchases made by the intervention (rural kibbutz with 493 adults and 214 children) and control groups (two rural kibbutzim with a total of 487 adults and 206 children) before and after the community culinary coaching programme, and changes within and between groups, Israel, November 2012-October 2013

\begin{tabular}{|c|c|c|c|c|c|c|c|c|c|}
\hline & Legumes & $\begin{array}{l}\text { Wholegrain } \\
\text { products }\end{array}$ & Fruits & Nuts & Vegetables & Alcohol & $\begin{array}{l}\text { MUFA/ } \\
\text { SFA }\end{array}$ & $\begin{array}{l}\text { Processed } \\
\text { meats }\end{array}$ & Fish \\
\hline \multicolumn{10}{|l|}{ Intervention group* } \\
\hline $\begin{array}{l}\text { Before the } \\
\text { intervention }(\mathrm{kg})\end{array}$ & 846 & 425 & 28473 & 65 & 34663 & NA & $3 \cdot 73$ & 7073 & 627 \\
\hline $\begin{array}{l}12 \text { months from } \\
\text { initiation }(\mathrm{kg}) \dagger\end{array}$ & 974 & 966 & 27900 & 71 & 37941 & NA & $4 \cdot 89$ & 5878 & 1354 \\
\hline $\begin{array}{l}\text { Change (\%) } \\
P \ddagger\end{array}$ & $\begin{array}{l}+15 \\
<0.001\end{array}$ & $\begin{array}{l}+127 \\
<0.0001\end{array}$ & $\begin{array}{l}-2 \\
0.09\end{array}$ & $\begin{array}{l}+15 \\
<0.001\end{array}$ & $\begin{array}{l}+9 \\
<0.001\end{array}$ & $\begin{array}{l}\text { NA } \\
\text { NA }\end{array}$ & $\begin{array}{l}+31 \\
<0.0001\end{array}$ & $\begin{array}{l}-17 \\
<0.0001\end{array}$ & $\begin{array}{l}+116 \\
\quad<0.0001\end{array}$ \\
\hline \multicolumn{10}{|l|}{ Control group* } \\
\hline $\begin{array}{l}\text { Before the } \\
\text { intervention }(\mathrm{kg})\end{array}$ & 1100 & 1290 & 5453 & 48 & 27633 & NA & $18 \cdot 91$ & 6468 & 1052 \\
\hline $\begin{array}{l}12 \text { months from } \\
\text { initiation }(\mathrm{kg}) \dagger\end{array}$ & 970 & 983 & 4768 & 80 & 26261 & NA & $3 \cdot 83$ & 5614 & 780 \\
\hline $\begin{array}{l}\text { Change (\%) } \\
P \ddagger\end{array}$ & $\begin{array}{l}-12 \\
<0.001\end{array}$ & $\begin{array}{l}-24 \\
<0.0001\end{array}$ & $\begin{array}{l}-13 \\
<0.001\end{array}$ & $\begin{array}{l}+67 \\
<0.0001\end{array}$ & $\begin{array}{l}-5 \\
0.008\end{array}$ & $\begin{array}{l}\text { NA } \\
\text { NA }\end{array}$ & $\begin{array}{l}-80 \\
<0.0001\end{array}$ & $\begin{array}{l}-13 \\
<0.001\end{array}$ & $\begin{array}{l}-26 \\
<0.0001\end{array}$ \\
\hline$P \S$ & $<0.0001$ & $<0.0001$ & $<0.001$ & $<0.001$ & $<0.001$ & NA & $<0.0001$ & 0.004 & $<0.0001$ \\
\hline
\end{tabular}

NA, not applicable (alcoholic beverages are not served in this setting).

$P$ values are adjusted for differences between groups in age, having children and country of origin

${ }^{*}$ Total food items which were purchased by the kitchen during a 3-month interval; kilograms and percentage of the total.

†Weight was adjusted to the total food weight change in each group.

‡Difference over time within each group.

$\S$ Difference in change over time between groups.

Table 3 NOVA classification of food purchases made by the intervention (rural kibbutz with 493 adults and 214 children) and control groups (two rural kibbutzim with a total of 487 adults and 206 children) before and after the community culinary coaching programme, and changes within and between groups, Israel, November 2012-October 2013

\begin{tabular}{|c|c|c|c|c|c|c|c|c|c|}
\hline \multirow[b]{2}{*}{ NOVA classification } & \multicolumn{4}{|c|}{ Intervention group* } & \multicolumn{4}{|c|}{ Control group* } & \multirow[b]{2}{*}{$P \S$} \\
\hline & $\begin{array}{l}\text { Before the } \\
\text { intervention } \\
(\mathrm{kg})\end{array}$ & $\begin{array}{l}12 \text { months from } \\
\text { initiation }(\mathrm{kg}) \dagger\end{array}$ & $\begin{array}{c}\text { Change } \\
(\%)\end{array}$ & $P \ddagger$ & $\begin{array}{l}\text { Before the } \\
\text { intervention } \\
(\mathrm{kg})\end{array}$ & $\begin{array}{l}12 \text { months from } \\
\text { initiation }(\mathrm{kg}) \dagger\end{array}$ & $\begin{array}{c}\text { Change } \\
(\%)\end{array}$ & $P \ddagger$ & \\
\hline $\begin{array}{l}\text { Unprocessed or } \\
\text { minimally processed } \\
\text { foods }\end{array}$ & 84549 & 90094 & +7 & 0.01 & 50484 & 49054 & -3 & 0.59 & $<0.001$ \\
\hline $\begin{array}{l}\text { Processed culinary } \\
\text { ingredients }\end{array}$ & 2711 & 2561 & -6 & 0.39 & 3837 & 3929 & +2 & 0.33 & $0 \cdot 16$ \\
\hline Processed foods & 16989 & 15512 & -9 & 0.09 & 13473 & 12304 & -9 & 0.28 & 0.47 \\
\hline Ultra-processed foods & 13679 & 10718 & -22 & $<0.001$ & 12680 & 13662 & +8 & 0.21 & $<0.001$ \\
\hline
\end{tabular}

$P$ values are adjusted for differences between groups in age, having children and country of origin.

${ }^{*}$ Total food items which were purchased by the kitchen during a 3-month interval; kilograms and percentage of the total.

†Weight was adjusted to the total food weight change in each group.

‡Difference over time within each group.

$\S$ Difference in change over time between groups.

improving cafeteria food ${ }^{(39-41)}$, this is the first description of a CBPR that gave the community (both members and cafeteria leadership) an exclusive decision-making role in determining the programme's nutritional goals and the pace of their implementation.

Several factors had the potential to dilute the cafeteria's nutritional change, including the gradual pace of the coaching and the layperson leadership ${ }^{(20)}$. However, most Mediterranean index and NOVA classification outcomes demonstrated significant positive changes 12 months from programme initiation compared with control. The only Mediterranean index category that did not improve at 12 months is fruits. In addition to the fact that fruits were not included in any of the programme goals, it should be noted that between 2012 and 2013 the increase in the Israeli fruits and vegetables price index was higher ( $7.52 \%)$ than the increase in the Israeli food price index without fruits and vegetables (6.10\%), which may have impacted purchasing. This positive change in cafeteria food might have clinical significance for diners. For example, while a recent study found that a $10 \%$ increase in the proportion of ultra-processed foods in the diet was associated with a significant increase of $12 \%$ in the risk of overall cancer ${ }^{(30)}$, the decrease of the proportion of ultraprocessed foods in the present study was $22 \%$.

Cafeteria interventions are usually led by experts and include methods such as food labelling and food architecture $^{(8)}$. Interestingly, the community cafeteria leadership, 
Table 4 Community members' satisfaction with the cafeteria food in the intervention (rural kibbutz with 493 adults and 214 children) and control groups (two rural kibbutzim with a total of 487 adults and 206 children) before and after the community culinary coaching programme, and changes within and between groups, Israel, November 2012-October 2013

\begin{tabular}{|c|c|c|c|c|c|c|c|c|c|c|c|}
\hline & \multicolumn{5}{|c|}{ Intervention group } & \multicolumn{5}{|c|}{ Control group } & \multirow[b]{3}{*}{$P+$} \\
\hline & \multicolumn{2}{|c|}{$\begin{array}{l}\text { Before the } \\
\text { intervention }\end{array}$} & \multicolumn{2}{|c|}{$\begin{array}{l}12 \text { months } \\
\text { from initiation }\end{array}$} & \multirow[b]{2}{*}{$P^{\star}$} & \multicolumn{2}{|c|}{$\begin{array}{l}\text { Before the } \\
\text { intervention }\end{array}$} & \multicolumn{2}{|c|}{$\begin{array}{l}12 \text { months } \\
\text { from initiation }\end{array}$} & \multirow[b]{2}{*}{$P^{\star}$} & \\
\hline & Mean & SD & Mean & SD & & Mean & SD & Mean & SD & & \\
\hline \multicolumn{12}{|c|}{ Rate your satisfaction from the food prepared in the central kitchen in related to: } \\
\hline Breakfast/taste & 3.0 & 0.74 & 3.2 & 0.66 & 0.09 & $2 \cdot 7$ & 0.76 & 2.9 & 0.75 & 0.31 & 0.69 \\
\hline Breakfast/variety & 3.0 & 0.84 & 3.3 & 0.67 & 0.007 & $2 \cdot 7$ & 0.83 & 2.9 & 0.75 & 0.11 & 0.36 \\
\hline Breakfast/health & $3 \cdot 0$ & 0.72 & $3 \cdot 3$ & 0.64 & 0.01 & $2 \cdot 9$ & 0.80 & $3 \cdot 0$ & 0.82 & 0.54 & 0.31 \\
\hline Breakfast/overall & $3 \cdot 1$ & 0.74 & 3.3 & 0.60 & 0.02 & $2 \cdot 7$ & 0.76 & 2.9 & 0.79 & 0.34 & 0.66 \\
\hline Lunch/taste & 2.4 & 0.72 & $2 \cdot 8$ & 0.73 & $<0.001$ & $2 \cdot 6$ & 0.76 & 2.9 & 0.71 & 0.02 & 0.21 \\
\hline Lunch/variety & $2 \cdot 6$ & 0.80 & $2 \cdot 9$ & 0.74 & $<0.001$ & $2 \cdot 8$ & 0.75 & $3 \cdot 0$ & 0.73 & 0.03 & 0.57 \\
\hline Lunch/health & $2 \cdot 1$ & 0.74 & $2 \cdot 7$ & 0.77 & $<0.0001$ & $2 \cdot 4$ & 0.78 & 2.5 & 0.86 & 0.55 & $<0.0001$ \\
\hline Lunch/overall & 2.4 & 0.78 & $2 \cdot 8$ & 0.73 & $<0.0001$ & $2 \cdot 7$ & 0.73 & $2 \cdot 8$ & 0.76 & 0.11 & 0.03 \\
\hline Dinner/taste & $2 \cdot 0$ & 0.79 & $2 \cdot 2$ & 0.73 & 0.009 & $2 \cdot 2$ & 0.76 & $2 \cdot 4$ & 0.75 & 0.02 & 0.66 \\
\hline Dinner/variety & $2 \cdot 1$ & 0.74 & $2 \cdot 7$ & 0.77 & 0.02 & $2 \cdot 4$ & 0.78 & 2.5 & 0.86 & 0.24 & 0.002 \\
\hline Dinner/health & $2 \cdot 3$ & 0.83 & $2 \cdot 4$ & 0.84 & 0.44 & $2 \cdot 2$ & 0.78 & 2.5 & 0.85 & 0.009 & $0 \cdot 16$ \\
\hline Dinner/overall & 1.9 & 0.80 & $2 \cdot 1$ & 0.75 & 0.01 & $2 \cdot 1$ & 0.78 & $2 \cdot 3$ & 0.79 & 0.02 & 0.74 \\
\hline Friday dinner/taste & $2 \cdot 7$ & $0 \cdot 81$ & $2 \cdot 7$ & 0.75 & 0.71 & $2 \cdot 6$ & 0.79 & 2.9 & 0.77 & $<0.0001$ & 0.003 \\
\hline Friday dinner/variety & 2.5 & 0.94 & $2 \cdot 7$ & 0.87 & 0.03 & 2.4 & 0.87 & $2 \cdot 8$ & 0.85 & $<0.0001$ & 0.14 \\
\hline Friday dinner/health & $2 \cdot 0$ & $0 \cdot 80$ & 2.4 & 0.81 & $<0.0001$ & $2 \cdot 2$ & 0.77 & 2.5 & 0.79 & 0.002 & 0.24 \\
\hline Friday dinner/overall & $2 \cdot 4$ & 0.91 & $2 \cdot 6$ & 0.83 & 0.005 & $2 \cdot 4$ & 0.80 & $2 \cdot 8$ & 0.80 & $<0.0001$ & 0.17 \\
\hline Food freshness & $2 \cdot 7$ & 0.77 & 2.9 & 0.70 & 0.004 & $2 \cdot 8$ & 0.76 & $2 \cdot 8$ & 0.71 & 0.54 & $0 \cdot 16$ \\
\hline Protein dishes/variety & 2.5 & 0.77 & $2 \cdot 8$ & 0.74 & $<0.0001$ & $2 \cdot 7$ & 0.77 & 2.9 & 0.74 & 0.21 & 0.12 \\
\hline Protein dishes/taste & $2 \cdot 4$ & 0.73 & $2 \cdot 6$ & 0.73 & $<0.0001$ & $2 \cdot 6$ & 0.76 & $2 \cdot 7$ & 0.71 & 0.14 & 0.21 \\
\hline Vegetable side dishes/variety & 2.5 & 0.86 & 2.9 & 0.81 & $<0.001$ & $2 \cdot 7$ & 0.79 & $2 \cdot 8$ & 0.69 & 0.44 & $<0.001$ \\
\hline Vegetable side dishes/taste & $2 \cdot 3$ & 0.88 & $2 \cdot 7$ & 0.85 & $<0.0001$ & 2.5 & 0.83 & $2 \cdot 6$ & 0.70 & 0.41 & 0.006 \\
\hline Starch dishes/variety & $2 \cdot 4$ & 0.78 & $2 \cdot 7$ & 0.73 & $<0.0001$ & $2 \cdot 8$ & 0.75 & $2 \cdot 8$ & 0.73 & 0.73 & $<0.001$ \\
\hline Starch dishes/taste & 2.4 & 0.77 & $2 \cdot 7$ & 0.75 & $<0.0001$ & $2 \cdot 6$ & 0.77 & $2 \cdot 6$ & 0.72 & 0.84 & 0.006 \\
\hline Soups/variety & $2 \cdot 7$ & 0.84 & 3.0 & 0.78 & $<0.001$ & $2 \cdot 3$ & 0.90 & $2 \cdot 6$ & 0.86 & $<0.001$ & 0.94 \\
\hline Soups/taste & $2 \cdot 6$ & 0.88 & 2.9 & 0.81 & $<0.001$ & $2 \cdot 3$ & 0.88 & 2.5 & 0.85 & 0.02 & 0.61 \\
\hline Salads/variety & 2.9 & 0.81 & $3 \cdot 1$ & 0.77 & 0.005 & 2.9 & 0.76 & 2.9 & 0.79 & 0.81 & 0.03 \\
\hline Salads/taste & $2 \cdot 6$ & 0.86 & $2 \cdot 9$ & 0.81 & $<0.001$ & $2 \cdot 7$ & 0.83 & $2 \cdot 8$ & 0.81 & 0.12 & 0.19 \\
\hline Fruits/variety & $2 \cdot 3$ & 0.87 & 2.4 & 0.80 & 0.74 & $2 \cdot 0$ & 1.03 & $2 \cdot 1$ & 1.01 & 0.43 & 0.85 \\
\hline Food presentation & $2 \cdot 8$ & 0.79 & 2.9 & 0.70 & 0.004 & $2 \cdot 6$ & 0.82 & $2 \cdot 8$ & 0.79 & 0.12 & 0.31 \\
\hline Food saltiness & $2 \cdot 2$ & 0.93 & $2 \cdot 3$ & 0.85 & 0.64 & $2 \cdot 3$ & 0.89 & 2.5 & 0.86 & 0.006 & 0.13 \\
\hline
\end{tabular}

$P$ values are adjusted for differences between groups in age, having children and country of origin, and are adjusted (increased) to control the false discovery rate at 0.05 using the method of Benjamini and Hochberg ${ }^{(38)}$.

*Difference over time within each group.

†Difference in change over time between groups.

which was equally involved in designing the intervention ${ }^{(20)}$, preferred other methods such as improving cooking processes and supplies ${ }^{(20)}$. The positive nutritional outcomes suggest that culinary education might be a promising method for future cafeteria interventions. Further, the intent of the kitchen staff to continue the intervention beyond its 1-year time frame ${ }^{(20)}$ suggests that culinary coaching might melt kitchen staff's resistance to change ${ }^{(11)}$ towards sustainable change. Future research is required to evaluate the impact of culinary training including culinary coaching in other cafeteria settings.

The participant-centred culinary coaching process might also have helped acceptance of the nutritional change by the community members. While the community leadership was concerned that shifting to healthier food would result in objections, diners' consumption habits did not change significantly and satisfaction with the cafeteria food improved. Outcomes show that the baseline use of the cafeteria was high (average of 5.6 lunches/week) and that a decrease in its use was not reported. Further, although several food items, which are usually appreciated, were reduced significantly (e.g. mayonnaise-based salads, burgers) or removed (e.g. salami, sweetened corn) from the cafeteria menu ${ }^{(20)}$, overall members' satisfaction with the cafeteria food increased 12 months after programme initiation. Members' satisfaction from domains that were not addressed by the intervention (e.g. Friday dinners) ${ }^{(20)}$ were also improved. This might relate to the overall increase in members' satisfaction or to a general improvement in the kitchen staff's cooking methods. Although twenty-five satisfaction items of the intervention community were significantly improved, changes in only nine improved selectively in the intervention group. This might be due to a change of the kitchen staff leadership at one of the control community cafeterias that resulted in improved satisfaction, or a difference between the intervention and control groups that is not reflected in the demographics (e.g. resistance to change, relationship with the kitchen leadership). 
Table 5 Diners' consumption habits in the intervention (rural kibbutz with 493 adults and 214 children) and control groups (two rural kibbutzim with a total of 487 adults and 206 children) before and after the community culinary coaching programme, and changes within and between groups, Israel, November 2012-October 2013

\begin{tabular}{|c|c|c|c|c|c|c|c|c|c|c|c|}
\hline & \multicolumn{5}{|c|}{ Intervention group } & \multicolumn{5}{|c|}{ Control group } & \multirow[b]{3}{*}{$P \dagger$} \\
\hline & \multicolumn{2}{|c|}{$\begin{array}{l}\text { Before the } \\
\text { intervention }\end{array}$} & \multicolumn{2}{|c|}{$\begin{array}{c}12 \text { months } \\
\text { from } \\
\text { initiation } \\
\end{array}$} & \multirow[b]{2}{*}{$P^{\star}$} & \multicolumn{2}{|c|}{$\begin{array}{l}\text { Before the } \\
\text { intervention }\end{array}$} & \multicolumn{2}{|c|}{$\begin{array}{c}12 \text { months } \\
\text { from } \\
\text { initiation }\end{array}$} & \multirow[b]{2}{*}{$P^{\star}$} & \\
\hline & Mean & SD & Mean & SD & & Mean & SD & Mean & SD & & \\
\hline $\begin{array}{l}\text { How many weekly breakfasts which were prepared by the central } \\
\text { kitchen are you consuming? (e.g. dine in, take away) } \ddagger\end{array}$ & $3 \cdot 1$ & $2 \cdot 70$ & $3 \cdot 0$ & $2 \cdot 64$ & 0.41 & $2 \cdot 2$ & $2 \cdot 62$ & $2 \cdot 2$ & $2 \cdot 74$ & 0.98 & 0.78 \\
\hline $\begin{array}{l}\text { How many weekly lunches which were prepared by the central } \\
\text { kitchen are you consuming? (e.g. dine in, take away) } \ddagger\end{array}$ & $5 \cdot 6$ & 1.89 & $5 \cdot 5$ & 1.92 & 0.72 & 4.7 & $2 \cdot 31$ & $5 \cdot 1$ & $2 \cdot 02$ & 0.09 & 0.17 \\
\hline $\begin{array}{l}\text { How many weekly dinners which were prepared by the central } \\
\text { kitchen are you consuming? (e.g. dine in, take away) } \ddagger\end{array}$ & $3 \cdot 2$ & $2 \cdot 20$ & $2 \cdot 9$ & $2 \cdot 24$ & 0.38 & $2 \cdot 6$ & $2 \cdot 27$ & $2 \cdot 8$ & $2 \cdot 35$ & 0.61 & 0.34 \\
\hline $\begin{array}{l}\text { How many weekly family meals are you having? (at least one } \\
\text { parent with a few of the children) } \ddagger\end{array}$ & $3 \cdot 3$ & $2 \cdot 45$ & $3 \cdot 5$ & $2 \cdot 52$ & 0.64 & $3 \cdot 1$ & $2 \cdot 50$ & $3 \cdot 1$ & $2 \cdot 52$ & 0.94 & 0.81 \\
\hline On average, how often do you refill your plate in a meal?§ & $1 \cdot 2$ & 0.45 & $1 \cdot 2$ & 0.54 & 0.41 & 1.4 & 0.54 & 1.4 & 0.63 & 0.39 & 0.99 \\
\hline
\end{tabular}

Community members' self-reported behaviours.

$P$ values are adjusted for differences between groups in age, having children and country of origin, and are adjusted (increased) to control the false discovery rate at 0.05 using the method of Benjamini and Hochberg ${ }^{(38)}$.

*Difference over time within each group.

†Difference in change over time between groups.

‡Response: 1-7 per week.

$\S$ Response: free text (number).

\section{Strengths and limitations of study}

The current study adds to a limited number of studies that used objective outcomes such as sales data to evaluate the impact of cafeteria interventions ${ }^{(9,10)}$. The analysis of these outcomes using comprehensive objective tools such as the Mediterranean index and the NOVA classification, and the use of a control group, are key strengths of the study. While other studies analysed cafeteria sales data, the current study analysed the food items that were purchased by the kitchen. This rigid method provides comprehensive and accurate evidence of the food items that were used by the kitchen staff while cooking and serving the cafeteria food, as well as an opportunity to present the intervention costs. Further research is needed to demonstrate whether the increased costs are due to the use of more expensive food items or to bigger portions that were consumed by the diners.

The present study describes the impact of a CCCP in the unique community setting of a kibbutz. The CCCP success in this setting might be due to the closeness of community connections, and future research will need to determine whether other organizations where individuals eat some of their meals in a communal setting (e.g. schools, workplaces) might benefit from CCCP. Further, the control group respondents were somewhat younger, more had children under the age of 18 years and were composed of more immigrants than the intervention group. However, after adjusting for these variables, no changes were noted in the number of significant consumption habit/satisfaction item changes in both the intervention and control groups, thus it seems that these differences between communities were inconsequential in the study.

Other limitations include the inclusion of the kitchen food waste in the nutritional analysis (although professional kitchen waste is usually minimal compared with diner food waste) and the lack of a long-term follow-up. Further, despite the positive effect of the intervention on nutritional value of the purchased food, the study did not evaluate whether the intervention had any impact on members' health. Both the intervention and control communities are insured in the same health-care system; thus, we intend to collect their data and to evaluate the impact of this intervention on health and health-care costs.

\section{Conclusions and public health implications}

The current study suggests that the CCCP is an effective programme that was accepted by both community members and cafeteria staff. Although the CCCP decision-making model $^{(20)}$ grants communities an exclusive responsibility for determining both the nutritional goals and the pace of adopting them, the study's outcomes suggest nutritional benefits with an effect size that might impact diners' health. The CCCP, which considers both the community priorities and the kitchen staff confidence and readiness for a change, might be a useful model for improving the food served in cafeterias at working places and schools.

\section{Acknowledgements}

Acknowledgements: The authors would like to thank kibbutz Yotvata's members and leadership for teaching them how to implement a CBPR. Financial support: This work was sponsored by research grants from kibbutz Yotvata 
and the Israeli Association of Family Medicine. R.P. was supported through his fellowship with educational grants from Maccabi Healthcare Service, Harvard Medical School Physical Medicine and Rehabilitation department and the Israeli Cancer Association. The funders had no role in the design, analysis or writing of this article; kibbutz Yotvata leadership was an equal partner in designing the programme as described throughout the manuscript. Conflict of interest: The authors declare that they have no competing interests. R.P. received book royalties from Penn Publications and honoraria from the American College of Preventive Medicine and Hebrew University of Jerusalem for the development of a culinary medicine curriculum. Authorship: R.P. participated in the design and delivery of the programme, collection and analysis of data, and drafting the manuscript. D.P. led the analysis of the quantitative data and contributed significantly to the drafting of the manuscript. R.A. participated in the design and delivery of the programme, and collection and analysis of data. T.M. led the questionnaire development and participated in the manuscript drafting. E.M.B. participated in the design and delivery of the programme, analysis of data and drafting the manuscript. M.Z. participated in the design and delivery of the programme, and collection of data. Ethics of human subject participation: This study was conducted according to the guidelines laid down in the Declaration of Helsinki and all procedures involving research study participants were approved by the Clalit Health Service Institutional Review Board on Human Subjects Research (committee's reference number 003012-COM); and the need for participant consent was waived.

\section{Author ORCID. (D) Rani Polak, 0000-0002-6360-902X.}

\section{References}

1. Rosenberg E, Lev B, Bin-Nun G et al. (2008) Healthy Israel 2020: a visionary national health targeting initiative. Public Health 122, 1217-1225

2. International Diabetes Federation (2017) IDF diabetes atlas, 8th ed. http://www.idf.org/diabetesatlas (accessed July 2018).

3. Israeli Center for Disease Control, Israeli Ministry of Health (2014) Mabat cohort, national health and nutrition cohort survey ages 35-74 (in Hebrew). http://www.health.gov.il/ PublicationsFiles/mabat_cohort_2014.pdf (accessed May 2018).

4. Murray CJ, Atkinson C, Bhalla K et al. (2013) The state of US health, 1990-2010: burden of diseases, injuries, and risk factors. JAMA 310, 591-608.

5. Polak R, Phillips EM, Nordgren J et al. (2016) Health-related culinary education: a summary of representative emerging programs for health professionals and patients. Glob $A d v$ Health Med 5, 61-68.

6. Reicks M, Trofholz AC, Stang JS et al. (2014) Impact of cooking and home food preparation interventions among adults: outcomes and implications for future programs. J Nutr Educ Behav 46, 259-276.

7. Reicks M, Kocher M \& Reeder J (2018) Impact of cooking and home food preparation interventions among adults: a systematic review (2011-2016). J Nutr Educ Behav 50, 148-172.

8. Nørnberg TR, Houlby L, Skov LR et al. (2016) Choice architecture Interventions for increased vegetable intake and behavior change in a school setting: a systematic review. Perspect Public Health 136, 132-142.

9. Liu PJ, Roberto CA, Liu LJ et al. (2012) A test of different menu labeling presentations. Appetite 59, 770-777.

10. Thorndike AN, Riis J, Sonnenberg LM et al. (2014) Trafficlight labels and choice architecture: promoting healthy food choices. Am J Prev Med 46, 143-149.

11. Krishnaswami J, Martinson M, Wakimoto P et al. (2012) Community-engaged interventions on diet, activity, and weight outcomes in US schools: a systematic review. $A m \mathrm{~J}$ Prev Med 43, 81-91.

12. Avriel A, Fuchs L, Plakht Y et al. (2011) Quality of life at the Dead Sea region: the lower the better? An observational study. Health Qual Life Outcomes 9, 38.

13. Walter-Ginzburga A, Blumstein T \& Guralnik JM (2004) The Israeli kibbutz as a venue for reduced disability in old age: lessons from the Cross-sectional and Longitudinal Aging Study (CALAS). Soc Sci Med 59, 389-403.

14. Friedman A \& Lahad A (2001) Health behavior in a kibbutz population: correlations among different modalities of health care utilization. Isr Med Assoc 3, 898-902.

15. Ahmed SM \& Palermo AG (2010) Community engagement in research: frameworks for education and peer review. $A m \mathrm{~J}$ Public Health 100, 1380-1387.

16. Horowitz CR, Robinson M \& Seifer S (2009) Communitybased participatory research from the margin to the mainstream: are researchers prepared? Circulation 119, 2633-2642.

17. Polak R, Pober DM, Budd MA et al. (2017) Improving patients' home cooking - a case series of participation in a remote culinary coaching program. Appl Physiol Nutr Metab 42, 893-896.

18. Polak R, Sforzo GA, Dill D et al. (2015) Credentialed chefs as certified wellness coaches: call for action. Eating Behav 19 , 65-67.

19. Wolever RQ, Simmons LA, Sforzo GA et al. (2013) A systematic review of the literature on health and wellness coaching: defining a key behavioral intervention in healthcare. Glob Adv Health Med 2, 38-57.

20. Polak R, Pober DM, Morris A et al. (2018) Improving adherence to Mediterranean-style diet with a community culinary coaching program methodology development and process evaluation. J Ambul Care Manage 41, 181-193.

21. Polak R, Dill D, Abrahamson MJ et al. (2014) Innovation in diabetes care: improving consumption of healthy food through a 'chef coaching' program: a case report. Glob Adv Health Med 3, 42-48.

22. Bach-Faig A, Berry EM, Lairon D et al. (2011) Mediterranean diet pyramid today. Science and cultural updates. Public Health Nutr 14, 2274-2284.

23. Shai I, Schwarzfuchs D, Henkin Y et al.; Dietary Intervention Randomized Controlled Trial (DIRECT) Group (2008) Weight loss with a low-carbohydrate, Mediterranean, or low-fat diet. N Engl J Med 359, 229-241.

24. Sofi F, Cesari F, Abbate R et al. (2008) Adherence to Mediterranean diet and health status: meta-analysis. BMJ 337, a1344.

25. Schwarzfuchs D, Golan R \& Shai I (2012) Four-year follow-up after two-year dietary interventions. $N$ Engl J Med 367, 1373-1374.

26. Estruch R, Ros E, Salas-Salvadó J et al.; PREDIMED Study Investigators (2013) Primary prevention of cardiovascular disease with a Mediterranean diet. $N$ Engl J Med 368, 1279-1290. 
27. Schwingshackl L \& Hoffmann G (2014) Adherence to Mediterranean diet and risk of cancer: a systematic review and meta-analysis of observational studies. Int $J$ Cancer 135, 1884-1897.

28. Monteiro CA, Cannon G, Moubarac JC et al. (2018) The UN Decade of Nutrition, the NOVA food classification and the trouble with ultra-processing. Public Health Nutr 21, 5-17.

29. Mendona RD, Pimenta AM, Gea A et al. (2016) Ultraprocessed food consumption and risk of overweight and obesity: the University of Navarra Follow-Up (SUN) cohort study. Am J Clin Nutr 104, 1433-1440.

30. Mendona RD, Lopes AC, Pimenta AM et al. (2017) Ultra-processed food consumption and the incidence of hypertension in a Mediterranean cohort: the Seguimiento Universidad de Navarra Project. Am J Hypertens 30, 358-366.

31. Rauber F, Campagnolo PD, Hoffman DJ et al. (2015) Consumption of ultra-processed food products and its effects on children's lipid profiles: a longitudinal study. Nutr Metab Cardiovasc Dis 25,116-122.

32. Fiolet T, Srour B, Sellem L et al. (2018) Consumption of ultraprocessed foods and cancer risk: results from NutriNet-Santé prospective cohort. BMJ 360, k322.

33. Ministry of Health, Division of Health Economics, Department of Planning Surveys and Evaluation \& Central Bureau of Statistics (2006) Health and social profile of the localities in Israel 1998-2002. https://www.cbs.gov.il/he/publications/ DocLib/2002/profil_ishuvim02/pdf/print.pdf (accessed May 2018).
34. Trichopoulos D \& Lagiou P (2004) Mediterranean diet and overall mortality differences in the European Union. Public Health Nutr 7, 949-951.

35. Israel Central Bureau of statistics (2015) Israeli cost indexes (in Hebrew). http://www.cbs.gov.il/reader/cw_usr_view_SHTML? $\mathrm{ID}=345$ (accessed May 2018).

36. Sorensen G, Emmons K, Hunt MK et al.(1998) Implications of the results of community intervention trials. Annu Rev Public Health 19, 379-416.

37. National Insurance Institute of Israel (2007) The National Insurance Institute of Israel approach to the decisions offer as part of the 2008 economic policy (in Hebrew). https:// www.btl.gov.il/SiteCollectionDocuments/btl/Publications/ mifal_94.pdf (accessed May 2018).

38. Benjamini Y \& Hochberg Y (1995) Controlling the false discovery rate: a practical and powerful approach to multiple testing. J R Stat Soc Series B Stat Methodol 57, 289-300.

39. Bogart LM, Elliott MN \& Uyeda K (2011) Preliminary healthy eating outcomes of SNaX, a pilot communitybased intervention for adolescents. $J$ Adolesc Health $\mathbf{4 8}$, 196-202.

40. Wang MC, Rauzon S \& Studer N (2010) Exposure to a comprehensive school intervention increases vegetable consumption. J Adolesc Health 47, 74-82.

41. Black MM, Hager ER \& Le K (2010) Challenge! Health promotion/obesity prevention mentorship model among urban, black adolescents. Pediatrics 126, 280-288. 